\title{
Influence of Factors on the Development of the Russian Commercial Real Estate Market
}

\author{
Natalya E. Solovjeva, Belgorod State National Research University, 85 Pobedy Str., Belgorod, Russia. \\ Tatiana N. Fliginskin, Belgorod State National Research University, 85 Pobedy Str., Belgorod, Russia. \\ Angelica A. Gulko, Belgorod State National Research University, 85 Pobedy Str., Belgorod, Russia. \\ Natalya A. Kalutskaya, Belgorod State National Research University, 85 Pobedy Str., Belgorod, Russia.
}

Svetlana B. Gladkova, St. Petersburg University of the Ministry of Internal Affairs of the Russian Federation, 1 Letchika

Pilyutova Street, Saint Petersburg, Russia; State Institute of Economics, Finance and Law, 5 Roshchinskaya Street, Gatchina, Russia.

\begin{abstract}
This article is devoted to the influence of trends, problems and barriers on the value of commercial real estate. The article presents figures positively characterizing demand for commercial real estate as the basis for entrepreneurial activities. The authors have analyzed the investment appeal of commercial real estate, defined risks influencing the disparity of commercial real estate prices and studied price dynamic for premises of free appointment in cities with a population over 1 million. As a result of the study, the authors have identified factors influencing the development of the commercial real estate market and have drawn some conclusions.
\end{abstract}

Keywords--- Investment Instruments, Commercial Real Estate, Real Estate, Real Estate Market, Real Estate Price.

\section{Introduction}

One of the important areas of investment is commercial real estate. The commercial real estate market is extremely attractive as an area of investment and, consequently, there are some problems hindering or influencing the development of the market.

This study aims to disclose and identify factors influencing the development of the commercial real estate market in Russia in order to increase business activity.

Problems related to the development of the commercial real estate market were studied by the following scholars: A.N. Asaul (2016), V.A. Goremykin (2011; 2016), N. Ordway (1997), G.M. Sternik (2000), J. Friedman (1997) and others.

One of the priorities for the development of the construction industry in Russia is increasing the investment attractiveness of commercial real estate projects. Approaches to the assessment of the business potential of investment-construction projects are considered in the publications by G. Untura, A. Evseyenko, A. Nesterenko, Z. Gerasimenhuk, Yu. M. Krasnov, O. Balatsky, A. Klimahin, A. Tishchenko, O. Grigorov, A. Lapidus, A. Feldman, O. Djukova, and others (Tsopa et al., 2018).

Russian commercial real estate is recognized as the research area. The study subject is tendencies in the development of the commercial real estate market in Russia.

\section{Methodology}

The study methodology is based on theoretical aspects and practice of Russian and foreign economists on the topic under study and includes such methods as the monographic method, analysis of obtained statistical data on the commercial real estate market, etc.

Based on the monographic method, an in-depth study of the research problem was carried out. A detailed description of commercial real estate objects revealed factors and risks affecting the pricing of real estate objects.

Statistical analysis of the data allowed us to identify the dynamics of the prices of commercial real estate, graphically present the dynamics of real estate prices, and draw conclusions.

We formulated the study goal and analyzed the commercial real estate market in the conditions of intensifying business activity. 


\section{Results and Discussion}

Commercial real estate accounts for most of the total real estate market both in the global economy and Russia. Commercial real estate is understood as a variety of real estate used to conduct business or entrepreneurial activities. For instance, abroad, the following indicators are considered for the purchase of real estate: location of real estate in prosperous districts of large European cities; new real estate facilities or real estate facilities after major renovation; lease agreements at the start of their validity; purchase of flat or apartments to be leased to students. The analysis of the existing practice shows that it is more efficient to use commercial real estate on lease terms. Consequently, investors see lower returns on investment of this sort, but liquidity, reliability and capitalization growth in the long term is higher. In addition, such real estate can be used for personal needs if necessary. This means that European countries apply territorial marketing where main directions of this business are the prestige of a district, its attractiveness or favorable natural or social resources and other positive conditions (Goremykin, 2016).

We analyzed the commercial real estate market, reviewing investment flows from the previous period (figure 1) and the price policy by type of real estate.

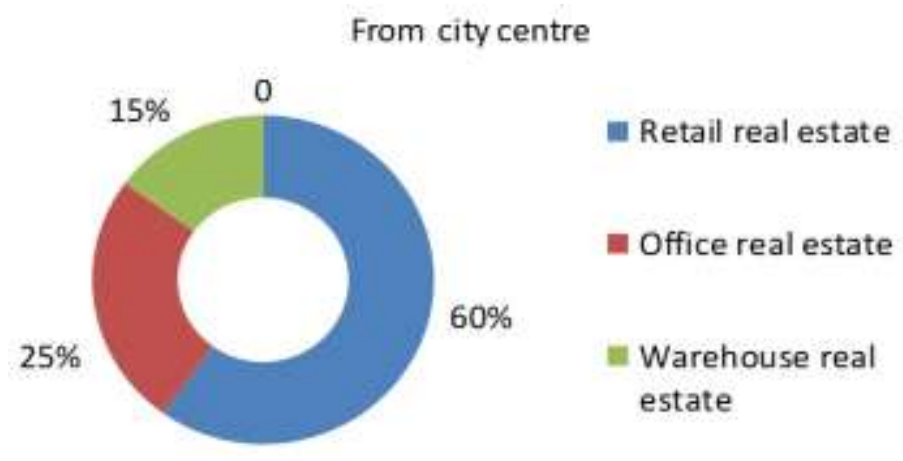

Figure 1: Investment Attractiveness of Commercial Real Estate Located Near the City Center in 2018

It is necessary to bear in mind and consider the fact that the price of real estate can vary because of factors influencing real estate pricing (Gudkova et al., 2017).

The analysis showed that the following macroeconomic factors can influence the investment appeal of commercial real estate: VAT growth, stricter license requirements, renovation of buildings in regions and economic instability.

Having studied concepts related to the development of commercial real estate, we identified problems and formulated factors influencing commercial real estate pricing (figure 2) and relevant risks (figure 3) (New trends in the real estate market, 2020).

\section{Prestige of the location of commercial real estate}

2. Infrastructure development of the territory where commercial real estate is located

3. Area of commercial real estate

4. Environmental conditions (natural resources) around the object of commercial real estate

5. Price disparity, supply and demand for commercial real estate

6. State of commercial real estate

Figure 2: Factors Affecting the Value of Commercial Real Estate

For the development of the commercial real estate market, it is essential to consider all factors and risks, bearing in mind both competition and influence of a country's internal and external policies. It is necessary to hold capital for business development and orientation in the market. At this stage of commercial real estate development, small office premises ranging from 15 to $35 \mathrm{~m}^{2}$ are in strong demand (Russian Ministry of Economic Development, 2019). 


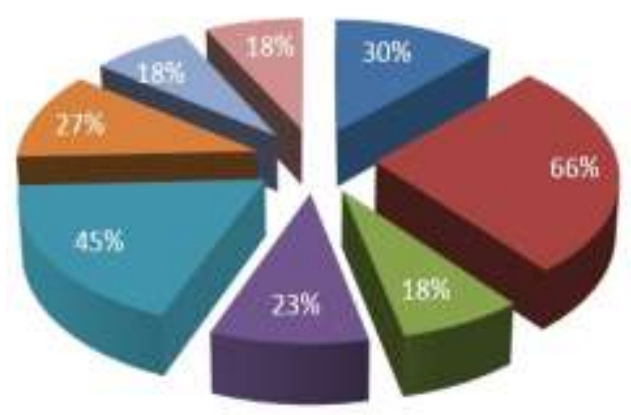

w Changing the terms of
financing
meduction of real incomes of
the population
$=$ Increase in material
prices/cost
=Strengthening competitors
$=$ Excessive regulation
$=$ Imperfect legislation
$=$ Lack of qualified workers

Figure 3: Influence of Risks on the Disparity of Prices for Commercial Real Estate

Thus, if sellers consider these factors and risks, they have more reasons to raise prices of specific real estate and if businessmen consider these factors when investing in commercial real estate, they are able to properly choose real estate for efficient business.

Proper analysis of the commercial real estate market helps entrepreneurs to avoid mistakes in management and decision-making (Onofrey, 2010).

Despite the aforementioned factors, the state economy influences the real estate market especially in terms of:

1. The economy's dependence on the commodity market;

2. A decline in oil prices that influence currency fluctuations leading to negative phenomena in the real estate market;

3. Bi-currency (Kotsarev and Fliginskikh, 2019).

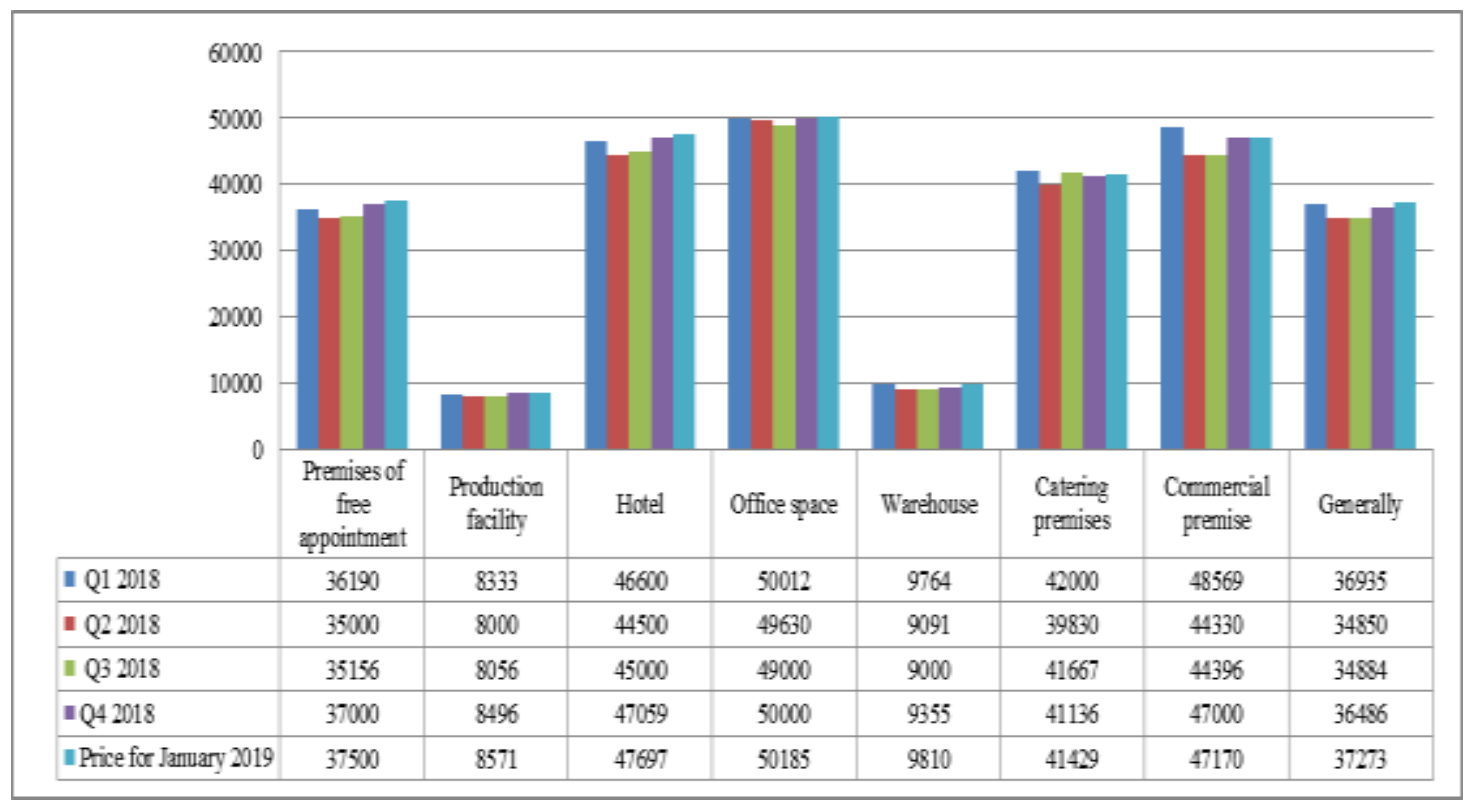

Figure 4: Dynamics of Prices by Types of Commercial Real Estate in Russia (rubles/m2) (Domofond.ru)

The analysis of changes in commercial real estate prices showed that the average price varies across the country (figure 4). Nationwide, real estate prices in the segment of premises of free appointment grew to $37,500 \mathrm{rubles} / \mathrm{m} 2$, followed by production facilities. Prices in the hotel segment grew to 47,697 rubles/m2 (2019 Overview of various sectors in the commercial real estate market). Against a backdrop of positive changes, there has been a negative 
trend in such segments, as catering and commercial premises. Despite this dynamic, several segments remained at the same level (office spaces and warehouses).

For detailed analysis, we considered pricing for premises of free appointment in cities with a population over 1 million (figure 5).

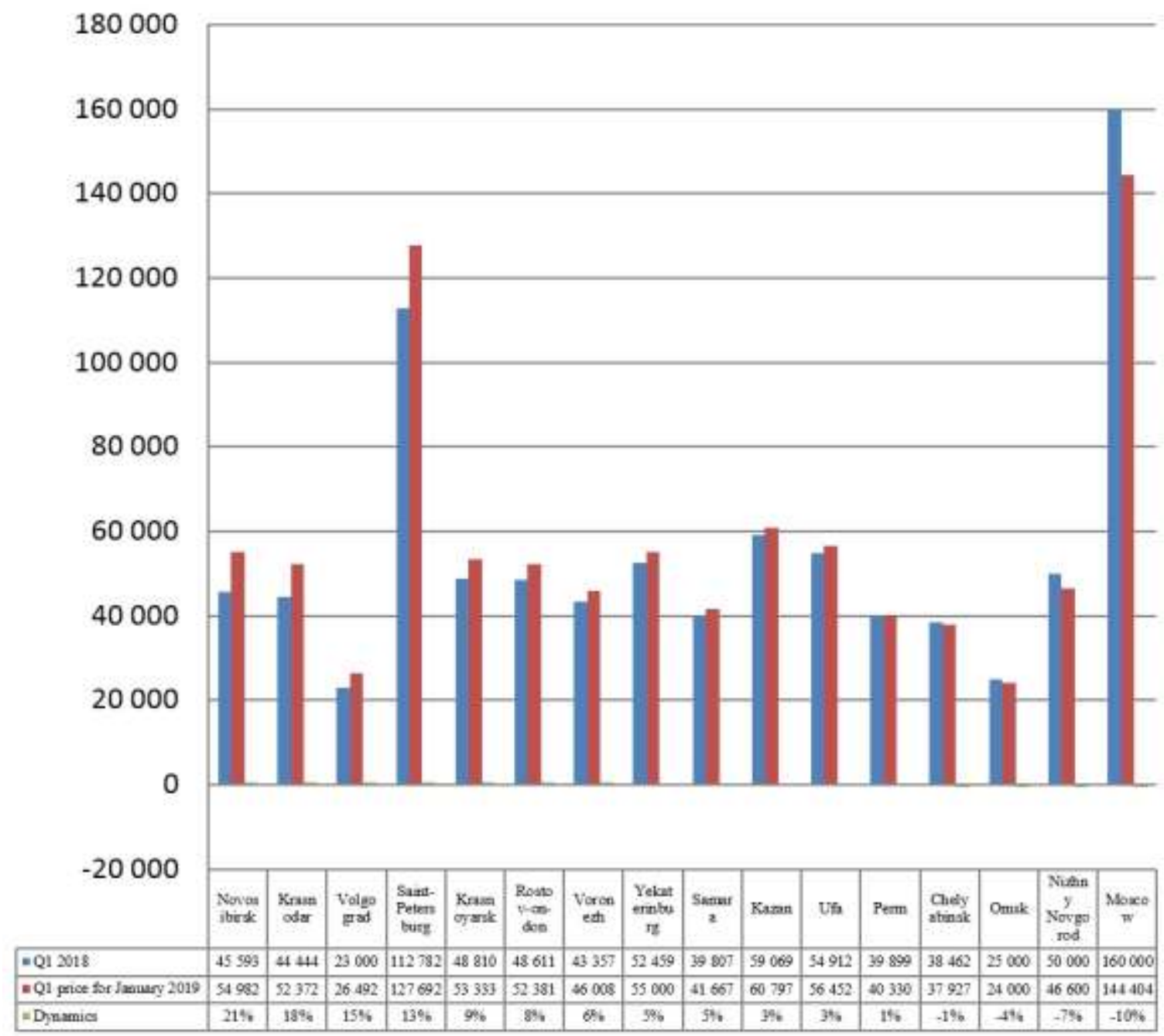

Figure 5: Dynamics of Prices for Premises of Free Appointment in cities with a Population Over 1 Million (Russia in Figures, 2019)

Large cities see the following trend: around a third to half of transactions account for premises of free appointment, depending on a city. Consequently, the study showed that businessmen have to wait for new highquality large office premises. As of late, entrepreneurs have begun to buy real estate in newly built apartment blocks for rent. They do so in the course of construction because real estate prices climb substantially after home transfer/acceptance acts are signed.

For this reason, commercial real estate management requires professionalism to maintain and improve the condition of assets (real estate), as well as to organize and forecast its development (Agafonov, 2011).

There are also changes in retail chains, making a gradual shift towards the city-popular format of street retail, including premises ranging from 50 to $80 \mathrm{~m} 2$. (Analysis of the Commercial Real Estate Market for 2019). Certainly, nobody benefits from prices, but in terms of profitability, these premises offer higher returns compared to premises located in residential blocks. Entrepreneurs buy commercial real estate in new residential facilities to open bakeries, pharmacies, mobile shops and small retail outlets. This is an attractive new business format corresponding to the requirements of current legislation (figure 6). 


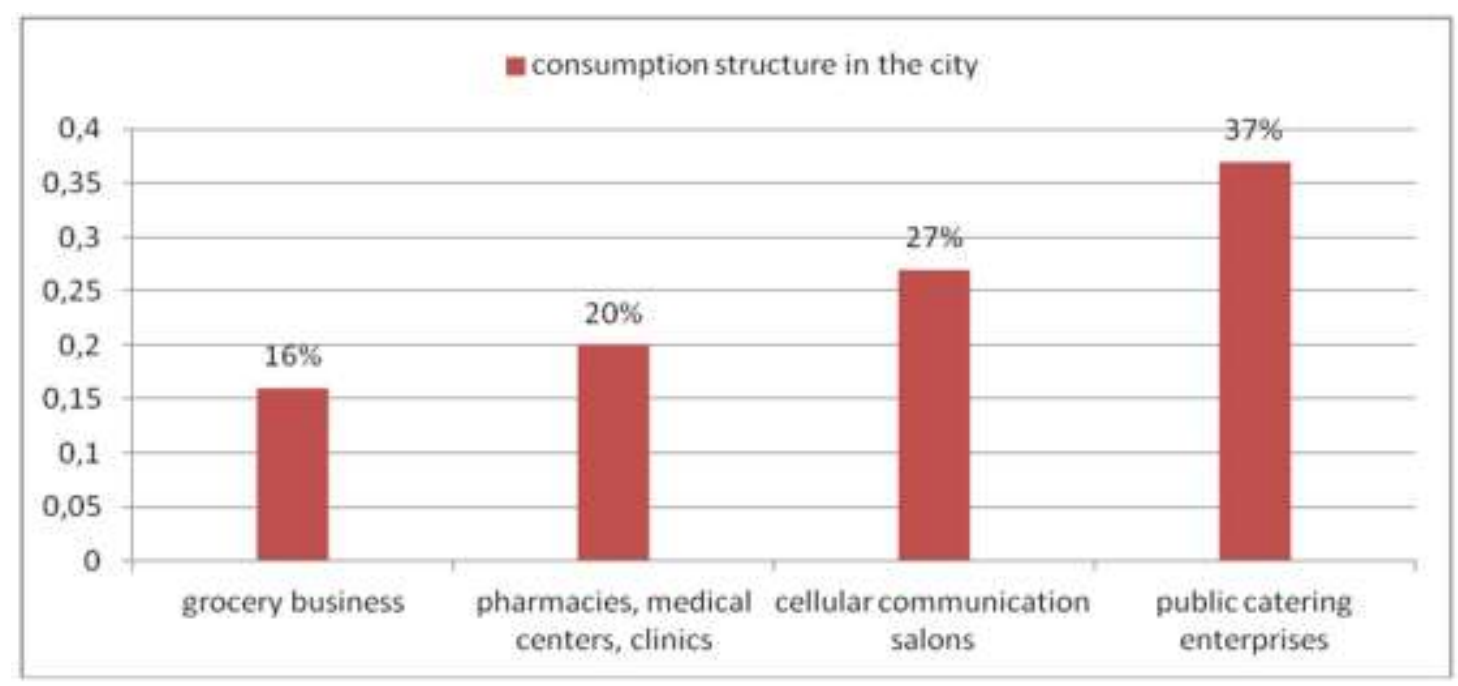

Figure 6: Main Consumers of City-format Commercial Real Estate

The analysis of the commercial real estate market showed that supply and demand, space of real estate offered and quality of facilities directly influence its price. It should also be noted that businessmen (buyers) have started paying less for rented facilities when transfer/acceptance acts are signed, except for branding-related activities, because the main term and standard for the sale of all commercial real estate are to provide premises with public utilities, engineering networks and other amenities. Consequently, a comprehensive, systematic approach to the formation and introduction of professional technologies and operating standards can synchronize market reforms and provide their high efficiency (Strenik, 2000).

\section{Conclusions}

Commercial real estate plays an important role in economic relations as any entrepreneurial activity or business requires the provision of assets. The main problem faced by commercial real estate owners is mistakes in real estate sales forecasts and inaccurate information on market trends. For this reason, for the effective use or sale of commercial real estate, it is essential to analyze supply and demand for real estate, real estate pricing policy and economic conditions in a country and consider identified factors and risks influencing the disparity of commercial real estate prices.

To develop the commercial real estate market, it is necessary to consider the aforementioned factors and improve legislative and statutory frameworks regulating relations in the real estate sector, which will contribute to enhancing business activities in Russia.

\section{References}

[1] Agafonov, M.I. Commercial real estate market development as a factor intensifying small entrepreneurship: PhD Thesis. Penza State University of Architecture and Construction, Penza, 2011.

[2] Ajaegbu, CHARLES CHIDOZIE. "Promoting foreign direct investment (FDI): The case of Uganda." International Journal of Research in Business Management 2.4 (2014): 73-94.

[3] Analysis of the commercial real estate market for 2019. Altera Invest. Retrieved from: https://alterainvest.ru/rus/blogi/analiz-rynka-kommercheskoy-nedvizhimosti-2019/

[4] Asaul, A.N., Starinsky, V.N., Asaul, M.A., Grakhova, E.V. Evaluation of real estate facilities. Publishing House Prospect, Moscow, 2016, pp. 384.

[5] BASKARAN, M., and R. CHANDRASEKARAN. "Study on the significance of economical planning for retirement community." International Journal of Business Management \& Research 6.3 (2016): 23-34.

[6] Friedman, D., Ordway, N. Income Property Appraisal and Analysis. Delo, Moscow, 1997, pp. 461.

[7] Goremykin, V.A. Real Estate Economics, 6th ed. Uright, Moscow, 2011, pp. 883.

[8] Goremykin, V.A. Real Estate Economics. 2(1).

[9] General model of the real estate market and the lease market, 8th ed. Uright, Lyubertsy, 2016, pp. 472.

[10] Gudkova, V.S., Ryakhimova, G.R., Smirnova, Yu.O. Influence of location on the price of real estate. Young Scientist. 11 (2017) 200-204 
[11] Ihuah, PAULINUS WOKA, C. H. U. K. W. U. E. M. E. K. A. Ekenta, and B. A. R. T. H. O. L. O. M. E. W. Nwokorie. "Impacts of inadequate infrastructures provision on real property value: a comparative study of Agbama and Ehimiri housing estate, Umuahia, Nigeria." International Journal of Environment, Ecology, Family and Urban Studies 4.4 (2014): 9-20..

[12] Khatib, Ahmad, and Steven Telford. "A Comparative Analysis of Selected Sectors of the Kuwaiti Economy." International Journal of Economics, Commerce and Research (IJECR), ISSN (P) (2018): 22500006.

[13] Kotsarev, A.A., Fliginskikh, T.N. Financial aspects of residential real estate in Russia. Economics and Entrepreneurship 5(106) (2019) 852-855.

[14] Ministry of Economic Development of the Russian Federation. 2019. Retrieved from: https://economy.gov.ru

[15] New trends in the real estate market 2020. Annual Study of the Russian Real Estate Market. PwC. Retrieved from: https://www.pwc.ru/ru/publications/etre-2020.html

[16] Official website: Obzor po itogam 2019 goda razlichnykh segmentov rynka kommercheskoi nedvizhimosti [2019 Overview of various sectors in the commercial real estate market]. Retrieved from: https://zdanie.info/2393/2467/news/13004

[17] Onofrey, D.I. Forecast for the commercial real estate market in entrepreneurial activities. Thesis for the degree of candidate of economic sciences: 08.00.05. State University of Management, Moscow, 2010. https://guu.ru/files/referate/onofrey.pdf

[18] Okoh, Victor PO, Uchenna Ebi, and Olusola O. Johnson. "Causes of Depreciation in Process Plants in Cement Industry: Analysis of the Perception of Practising Estate Surveyors and Valuers in Lagos and Ogun States." International Journal of Humanities and Social Sciences (IJHSS) 6.5 (2017): 109-116.

[19] Russia in Figures: Brief statistical collection. Moscow: Rosstat, 2019, pp. 549.

[20] Sternik, G.M. 2000. Systematic approach to the analysis of the real estate market. The Russian real estate market: analysis and forecast. Retrieved from: http://realtymarket.ru/metodi-eskie-materiali/sistemniipodhod-k-analizu-rinka-nedvijimosti-sternik-g-m.html

[21] Tsopa, N.V., Kovalskaya, L.S., Malachova, V.V. The Mechanism for Managing the Business Potential of Commercial Real Estate Projects. Materials Science Forum 931 (2018) 1220-1226. 